\title{
Retraction Note to: Model construction and empirical study on mobile commerce user satisfaction
}

\author{
Chaoyi $\mathrm{Xu}^{1}$ • Providence Alimasi Mongo ${ }^{1}$. Sherif Abdul Ganiyu ${ }^{1}$
}

Published online: 10 May 2021

(C) Springer Science+Business Media, LLC, part of Springer Nature 2021

\section{Retraction of: Current Psychology https://doi.org/10.1007/s12144-020-00877-z, published online 20 June 2020}

The Editor-in-Chief has retracted this article (Xu et al., 2020). The article was accepted as part of a guest-edited special issue in Current Psychology. Before the special issue was finalized, the Editor-in-Chief detected problems with editorial handling and peer review and decided not to proceed with the special issue. Post publication peer review found that this article is out of scope for the journal and does not meet the standards required by the journal.

None of the authors of this paper responded to any correspondence from the Editor about this retraction.

The online version of the original article can be found at https://doi.org/ 10.1007/s12144-020-00877-z

Chaoyi Xu

3910379@qq.com

Providence Alimasi Mongo

providenceal@yahoo.com

Sherif Abdul Ganiyu

abdulganiyusherif1@gmail.com

1 Anhui University of Science \& Technology, Huainan, Anhui, China
Update posted 06 August 2021

The Publisher would like to correct the above statement to acknowledge that Chao-yi $\mathrm{Xu}$ responded prior to publication of this notice and disagrees with the retraction.

\section{References}

Xu, C., Alimasi Mongo, P. Abdul Ganiyu, S. RETRACTED ARTICLE: Model construction and empirical study on mobile commerce user satisfaction. Curr Psychol 40, 35-43 (2021). https://doi.org/10. 1007/s12144-020-00877-z

Publisher's Note Springer Nature remains neutral with regard to jurisdictional claims in published maps and institutional affiliations. 